and nutritional evaluation of multigrain ready-to-eat snack mix from minor cereals. J. Food Sci. Technol., 2013, 51(12), 38123820 .

19. Muyonga, J. H., Andabati, B. and Ssepuuya, G., Effect of heat processing on selected grain amaranth physicochemical properties. Food Sci. Nutr., 2014, 2(1), 9-16.

20. Obatolu, V. A., Omucti, C. O. and Ebenerer, A. A., Qualities of extruded puffed snacks from maize/soybean mixture. J. Food Process Eng., 2016, 29, 149-161.

21. Mishra, G., Joshi, D. C. and Panda, B. K., Popping and puffing of cereal grains: a review. J. Grain Process. Storage, 2014, 1, 34-46.

22. Bunkar, D. S., Jha, A. and Mahajan, A., Optimization of the formulation and technology of pearl millet based 'ready-toreconstitute' kheer mix powder. J. Food Sci. Technol., 2012, 51, 2404-2414.

23. Oloyede, O. I., Chemical profile of unripe pulp of carica papaya Pak. J. Nutr., 2005, 4(6), 379-381.

24. Padmashree, A., Sharma, G. K. and Govindaraj, G., Development and evaluation of shelf stability of flaxoat nutty bar in different packaging materials. Food Nutr. Sci., 2013, 4, 538-546.

25. Mridula, K. K. and Singh, P., Barnwal development of Omega-3 rich energy bar with flaxseed. J. Food Sci. Technol., 2013, 50(5), 950-957.

26. Singh, G., Development of value-added products from pearl millet, Ph.D. thesis, Chaudhary Charan Singh Haryana Agricultural University, Hisar, Haryana, 2005.

27. Agbaje, R., Hassan, C. Z., Norlelawati, A., Rahman, A. and Huda, F. N., Development and physico-chemical analysis of granola formulated with puffed glutinous rice and selected dried sunnah foods. Int. Food Res. J., 2016, 23(2), 498-506.

28. Zamora-Gasga, V. M., Bello-Perez, L. A., Ortiz-Basurto, R. I., Tovar, J. and Sayago-Ayerdi, S. G., Granola bars prepared with Agave tequilana ingredients: chemical composition and in vitro starch hydrolysis. Food Sci. Technol., 2014, 56(2), 309-314.

29. Sharma, M., Mridula, D., Yadav, D. N. and Gupta, R. K., Physiochemical characteristics of maize and sorghum as affected by popping. Proc. Natl. Acad. Sci. India, Sect. B. Biol. Sci., 2015, 85(3), 794-799.

30. Ribnar, A. A., Designing sorghum (Designing Sorghum (Sorghum bicolor (L.) Moench) flakes-based snack bar for nutritional and health benefits of children, M.Sc. thesis, University of Agricultural Sciences, Dharwad, 2014.

31. Tibagonzeka, J., Wambete, J., Muyinda, A. M., Nakimbugwe, D. and Muyonga, J. H., Acceptability and nutritional contribution of grain amaranth recipes in Uganda. Afr. J. Food Agric. Nutr. Dev., 2014, 14(3), 8979-8997.

32. Verma, S., Khetrapaul, N. and Verma, V., Development and standardisation of protein rich sorghum based cereal bars. Int. J. Curr. Microbiol. App. Sci., 2018, 7(5), 2842-2849.

33. Taylor, J. R. N., Millet: Pearl. Encycl. Grain Sci., 2004, 2, $253-$ 261.

34. Dongxiao, S.-W., Teoh, A., Massarotto, C. and Wibisono, R., Comparative analysis of fruit-based functional bars. Food Chem., 2010, 119(4), 1369-1379.

35. Sharma, S. K., Chaudhary, S. P., Rao, V. K., Yadav, V. K. and Bisht, T. S., Standardization of technology for preparation and storage of wild apricot fruit bar. J. Food Sci. Technol., 2013, 50(4), 784-790.

36. Manthey, F. A., Sinha, S., Wolf-Hall, C. E. and Hall, C. A., Effect of flaxseed flour and packaging on shelf life of refrigerated pasta. J. Food Process. Preserv., 2008, 32(1), 75-87.

37. Hiremath, S. P., Physio-chemical characteristics of raw, malted and popped finger millet varieties, M.Sc. thesis, University of Agricultural Sciences, GKVK, Bengaluru, 2011.

38. Loveday, S. M., Hindmarsh, J. P., Creamer, L. K. and Singh, H., Physicochemical changes in a model protein bar during storage. Food Res. Int., 2009, 42(7), 798-806.
39. Kavitha, B., Vijayalakshmi, R., Yalagala, P. C. R., Illamaran, M. and Sugasini, D., Nutritional evaluation and cell viability of formulated probiotic millet fruit bar. J. Food Nutr. Disor., 2018, 7.

40. Muhammad, N., Rehman, S., Muhammad, A. F., Anjum, M. M. and Din Ghulam, M., Development, characterization, and optimization of protein level in date bars using response surface methodology. Sci. World J., 2012, 2012, 10; https://doi.org/10.1100/ 2012/518702.

41. Yang, Z. F., Zheng, Y. H., Cao, S. F., Tang, S. S., Ma, S. J. and $\mathrm{Li}, \mathrm{N}$., Effects of storage temperature on textural properties of Chinese bay berry fruit. J. Texture Stud., 2007, 38(1), 166-177.

42. Aggarwal, P. and Kaur, R. P., Development of intermediate moisture product from carrot pulp. Am. J. Food Sci. Nutr. Res., 2014, 1, 52-59.

43. Marotirao, P. C., Development of process technology for nutritional multigrain bar and storage studies, M.Tech. (Food Sci.) Thesis. Vasantrao Naik Marathwada Agricultural University, Parbhani, Maharashtra, 2017.

ACKNOWLEDGEMENTS. The authors are thankful to ICAR-IARI and KVK Ujwa, New Delhi for providing the necessary support and facilities for conducting the present investigation. The free and fair response provided by the panel judges is duly acknowledged.

Received 16 July 2020; revised accepted 22 January 2021

doi: $10.18520 / \mathrm{cs} / \mathrm{v} 120 / \mathrm{i} 8 / 1374-1381$

\section{Insights into the petrogenesis of depleted mantle dunite from the central part of the Nagaland-Manipur Ophiolites, North East India}

\author{
A. Krishnakanta Singh ${ }^{1, *}$, S. Khogenkumar ${ }^{2}$, \\ Santosh Kumar ${ }^{3}$, L. Romendro Singh ${ }^{4}$ and \\ S. S. Thakur ${ }^{1}$ \\ ${ }^{1}$ Wadia Institute of Himalayan Geology, Dehradun 248 001, India \\ ${ }^{2}$ National Centre for Polar and Ocean Research, Goa 403 804, India \\ ${ }^{3}$ Department of Geology, Kumaun University, Nainital 263 002, India \\ ${ }^{4}$ Department of Geology, Thoubal College, Thoubal 795 138, India
}

This communication presents results of mineral and whole-rock geochemistry of rarely occurred dunites in the central part of the Nagaland-Manipur Ophiolites (NMO), North East India, and discusses their genesis and tectonic evolution. These rocks are characterized by low concentration of average $\mathrm{CaO}(0.58 \mathrm{wt} \%)$, $\mathrm{Al}_{2} \mathrm{O}_{3}(0.42 \mathrm{wt} \%)$ and $\Sigma$ REE (1.24 ppm), but high Mg\# (0.91-0.92) and $\mathrm{Cr} \#(0.61-0.73)$ values in chromian spinels. They exhibit a U-shaped REE pattern depleted in MREEs, which is equivalent to dunite

*For correspondence. (e-mail: aksingh_wihg@rediffmail.com) 
composition, possibly part of a restite peridotite which underwent through extensive partial melting. The estimated degree of partial melting based on chromian spinel Cr\# ranged from $20.04 \%$ to $20.70 \%$. Low concentration of $\mathrm{TiO}_{2}(0.10-0.16 \mathrm{wt} \%)$ in chromian spinel in these dunites confirms no evidence of metasomatism. Therefore, we propose that dunites in the NMO represent the remnants of residual mantle wedge which underwent extensive partial melting in a subduction zone. Absence of metasomatism indicates no melt-wall rock interaction during the process of mantle melting and final obduction on the surface.

Keywords: Geochemistry, dunite, forearc, ophiolite, petrogenesis, supra-subduction.

THE mantle section in ophiolites has a multifaceted tectonic history involving melt-rock reaction, partial melting and deformation. Ophiolites can be generated in two main tectonic settings, viz. mid-ocean ridge (MOR) spreading centres and supra-subduction zone (SSZ) environments ${ }^{1-3}$. However, in some instances, other tectonic settings of continental margin, intraplate and volcanic-arc type can also produce ophiolites ${ }^{4-7}$. Existing theories have proposed that the Nagaland-Manipur Ophiolites (NMO) in North East India carry signatures of MOR, SSZ and plume-type features ${ }^{8-17}$, and all these facts point out many uncertainties in the earlier proposed petrogenetic evolution models of NMO. Continuous efforts are being made by various workers to understand the complex geological phenomenon involved during the process of NMO formation. One of the exciting and challenging topics in the NMO and other ophiolites studies globally is to understand the partial melting process of the mantle. Therefore, mantle rocks preserved in ophiolites are often targeted to extract the desired information of mantle melting. In this communication, new results of mineral and whole-rock chemistry derived from the representative samples of rarely occurring dunites from the central part of the NMO are presented. We also discuss its significance in this particular ophiolite section.

The NMO is a dismembered ophiolite suite of the larger Neo-tethyan ophiolite belt exposed along the IndoMyanmar Suture Zone which extends further south to the Andaman Island Arc and the Indonesian Island Arc (Figure $1 a$ ). It is composed of dismembered and imbricated sheets of residual mantle peridotites, mafic-ultramafic cumulates, mafic volcanic rocks dominated by basalt, mafic dykes, plagiogranite, chromitite pods and pelagic sediments (Figure $1 b$ ). The NMO has thrust contact with the Disang and Barail flysch sediments and is overthrusted from the east by continental metamorphic rocks.

The mantle rocks of the NMO constitute $95 \%$ of the ophiolites record in the NMO. Common mantle rocks available in this region are lherzolite and harzburgite, with minor amounts of dunite and chromitite. Sparse ultramafic-mafic cumulate (wehrlite, pyroxenite, gabbro) with minor mafic volcanic rocks (basalt, spilite) and mafic dyke (dolerite) are also encountered ${ }^{18-22}$. Podiform chromitites are rare in the study area despite their high economic value ${ }^{14,16}$. Dunites in the study area are often associated with harzburgite (Figure $2 a$ and $b$ ). They measured $\sim 250 \mathrm{~cm}$ in length and $\sim 105 \mathrm{~cm}$ in width, as observed in the field. Our sampling site was less than $2 \mathrm{~m}$ from the road and therefore we assume that large portions of the dunites in the area were destroyed due to road construction and other activities. Otherwise, the original size of the dunites must be much larger than that observed.

Table 1. Whole-rock chemistry of representative dunite samples of the Nagaland-Manipur Ophiolites (NMO), North East India

\begin{tabular}{|c|c|c|c|c|c|}
\hline Sample & $\mathrm{XA} / 1$ & $\mathrm{XA} / 2$ & $\mathrm{UT} / 1$ & $\mathrm{UT} / 2$ & $\mathrm{UT} / 3$ \\
\hline \multicolumn{6}{|l|}{ wt $\%$} \\
\hline $\mathrm{SiO}_{2}$ & 39.53 & 40.89 & 39.83 & 40.11 & 40.19 \\
\hline $\mathrm{TiO}_{2}$ & 0.01 & 0.01 & 0.01 & 0.02 & 0.01 \\
\hline $\mathrm{Al}_{2} \mathrm{O}_{3}$ & 0.12 & 0.18 & 0.17 & 0.19 & 0.15 \\
\hline $\mathrm{Fe}_{2} \mathrm{O}_{3}$ & 7.09 & 6.97 & 6.51 & 6.29 & 6.69 \\
\hline $\mathrm{MgO}$ & 45.89 & 44.46 & 45.38 & 45.12 & 44.91 \\
\hline $\mathrm{CaO}$ & 0.03 & 0.03 & 0.04 & 0.04 & 0.03 \\
\hline $\mathrm{Na}_{2} \mathrm{O}$ & 0.05 & 0.08 & 0.08 & 0.09 & 0.05 \\
\hline $\mathrm{K}_{2} \mathrm{O}$ & 0.01 & 0.03 & 0.02 & 0.01 & 0.01 \\
\hline $\mathrm{MnO}$ & 0.15 & 0.19 & 0.13 & 0.12 & 0.13 \\
\hline $\mathrm{P}_{2} \mathrm{O}_{5}$ & 0.01 & 0.01 & 0.02 & 0.01 & 0.01 \\
\hline LOI & 6.63 & 6.98 & 6.98 & 7.96 & 7.28 \\
\hline Total & 99.52 & 99.83 & 99.17 & 99.96 & 99.46 \\
\hline \multicolumn{6}{|l|}{ ppm } \\
\hline $\mathrm{Sc}$ & 4 & 7 & 2 & 4 & 3 \\
\hline $\mathrm{V}$ & 16 & 13 & 10 & 13 & 12 \\
\hline $\mathrm{Cr}$ & 2767 & 2271 & 2661 & 2562 & 2429 \\
\hline Co & 232 & 276 & 221 & 272 & 231 \\
\hline $\mathrm{Ni}$ & 2519 & 2486 & 2712 & 2622 & 2649 \\
\hline $\mathrm{Cu}$ & 26 & 33 & 18 & 24 & 31 \\
\hline $\mathrm{Zn}$ & 35 & 28 & 23 & 21 & 38 \\
\hline $\mathrm{Rb}$ & 0.13 & 0.11 & 0.12 & 0.11 & 0.13 \\
\hline $\mathrm{Sr}$ & 0.51 & 0.33 & 0.71 & 0.13 & 0.13 \\
\hline Y & 0.1 & 0.11 & 0.12 & 0.13 & 0.13 \\
\hline $\mathrm{Zr}$ & 0.11 & 0.16 & 0.12 & 0.13 & 0.13 \\
\hline $\mathrm{Nb}$ & 0.12 & 0.13 & 0.11 & 0.12 & 0.12 \\
\hline Th & 0.84 & 0.18 & 1.51 & 0.13 & 0.16 \\
\hline U & 0.04 & 0.02 & 0.02 & 0.01 & 0.03 \\
\hline $\mathrm{La}$ & 0.318 & 0.302 & 0.421 & 0.278 & 0.477 \\
\hline $\mathrm{Ce}$ & 0.653 & 0.621 & 0.695 & 0.598 & 0.859 \\
\hline $\operatorname{Pr}$ & 0.086 & 0.069 & 0.093 & 0.062 & 0.099 \\
\hline $\mathrm{Nd}$ & 0.303 & 0.301 & 0.328 & 0.278 & 0.398 \\
\hline $\mathrm{Sm}$ & 0.07 & 0.06 & 0.081 & 0.051 & 0.092 \\
\hline $\mathrm{Eu}$ & 0.017 & 0.015 & 0.021 & 0.014 & 0.028 \\
\hline $\mathrm{Gd}$ & 0.052 & 0.049 & 0.067 & 0.039 & 0.078 \\
\hline $\mathrm{Tb}$ & 0.009 & 0.008 & 0.011 & 0.006 & 0.012 \\
\hline Dy & 0.042 & 0.038 & 0.049 & 0.031 & 0.057 \\
\hline Ho & 0.009 & 0.008 & 0.01 & 0.006 & 0.011 \\
\hline Er & 0.031 & 0.026 & 0.033 & 0.023 & 0.038 \\
\hline $\mathrm{Tm}$ & 0.005 & 0.004 & 0.006 & 0.004 & 0.007 \\
\hline $\mathrm{Yb}$ & 0.04 & 0.037 & 0.046 & 0.031 & 0.052 \\
\hline $\mathrm{Lu}$ & 0.008 & 0.007 & 0.009 & 0.006 & 0.011 \\
\hline $\mathrm{La} / \mathrm{Yb}$ & 5.703 & 5.855 & 6.565 & 6.433 & 6.580 \\
\hline $\mathrm{La} / \mathrm{Sm}$ & 2.933 & 3.249 & 3.355 & 3.519 & 3.347 \\
\hline $\mathrm{Sm} / \mathrm{Yb}$ & 1.944 & 1.802 & 1.957 & 1.828 & 1.966 \\
\hline $\mathrm{Dy} / \mathrm{Yb}$ & 0.703 & 0.687 & 0.713 & 0.669 & 0.734 \\
\hline
\end{tabular}



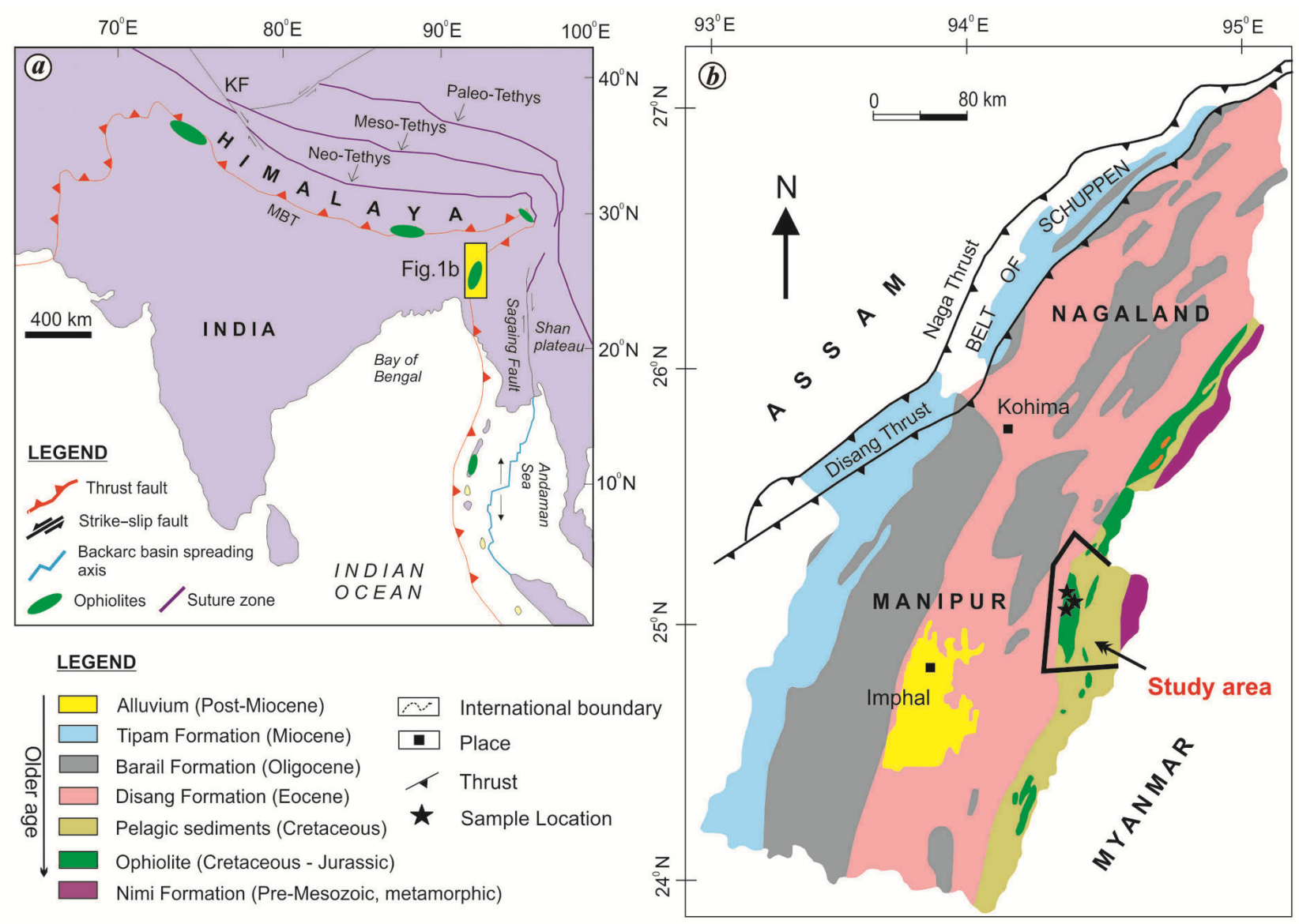

Figure 1. $\boldsymbol{a}$, Map showing plate boundaries and plate distribution, major continental blocks, suture zones and salient fault systems of the peri-Indian region. $\boldsymbol{b}$, Schematic geological map showing the distribution of various structural and stratigraphical units of the NagalandManipur Ophiolites (NMO), North East India (modified after Singh et al. ${ }^{21}$ and Vidyadharan et al ${ }^{43}$ ).
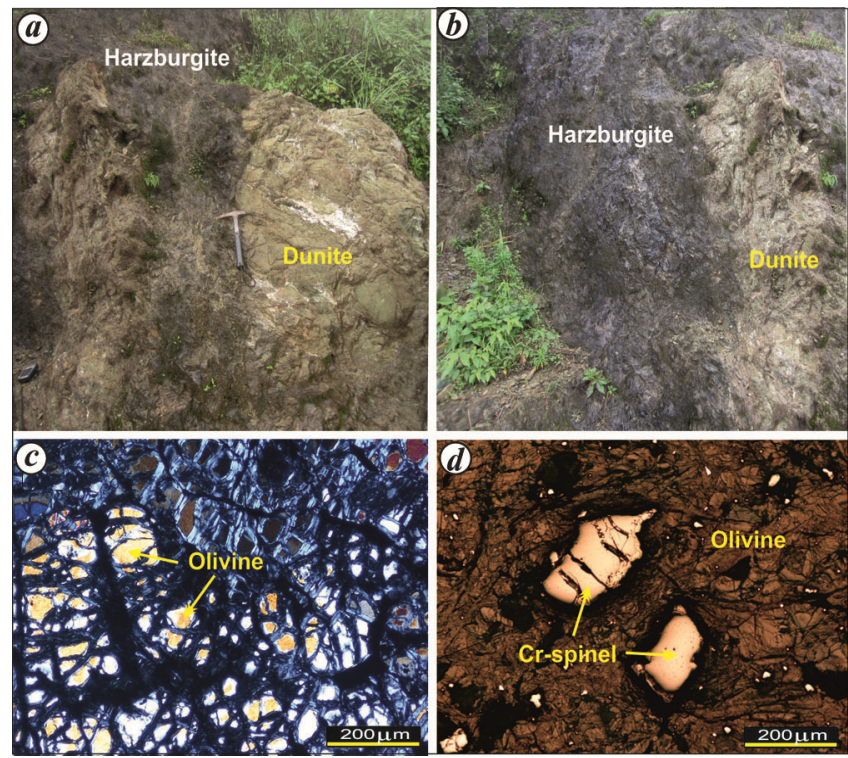

Figure 2. ( $(\boldsymbol{a}, \boldsymbol{b})$ Field photographs of dunite and associated harzburgite. Dunite exhibits distinct contact with harzburgite $(\boldsymbol{b}) .(\boldsymbol{c}, \boldsymbol{d})$ Representative photomicrographs of $(c)$ olivine grains in dunite (crosspolarized nicol) and (d) chrome-spinel, olivine and serpentine in dunite (transmitted light).

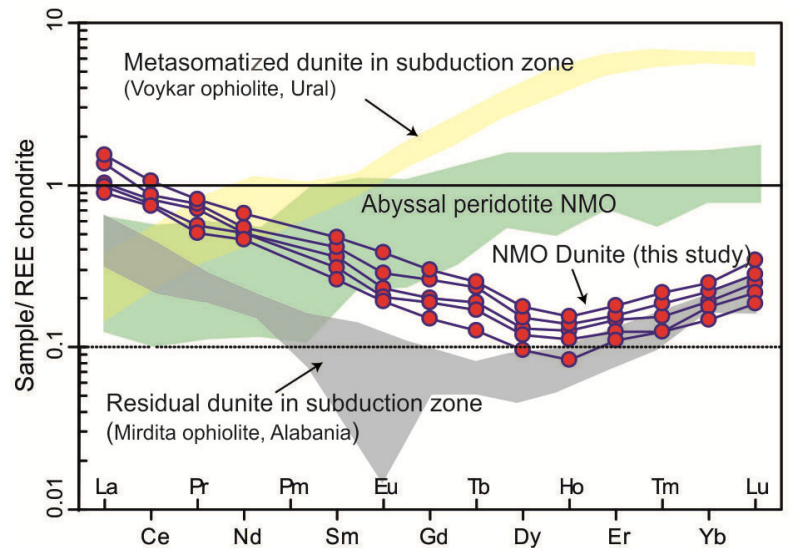

Figure 3. Chondrite normalized REE plots for representative dunite samples compared with the abyssal peridotites of $\mathrm{NMO}^{11}$. Metasomatized dunite in a subduction zone, Voykar ophiolite, $\mathrm{Ural}^{24}$ and residual dunite in a subduction zone, Mirdita ophiolite, Alabania ${ }^{25}$.

Under the microscope, the dunite samples are moderate to highly serpentinized and composed of olivine and chromian spinel with a small amount of bastite (pseudomorphs after orthopyroxene) (Figure $2 c$ and $d$ ). The 

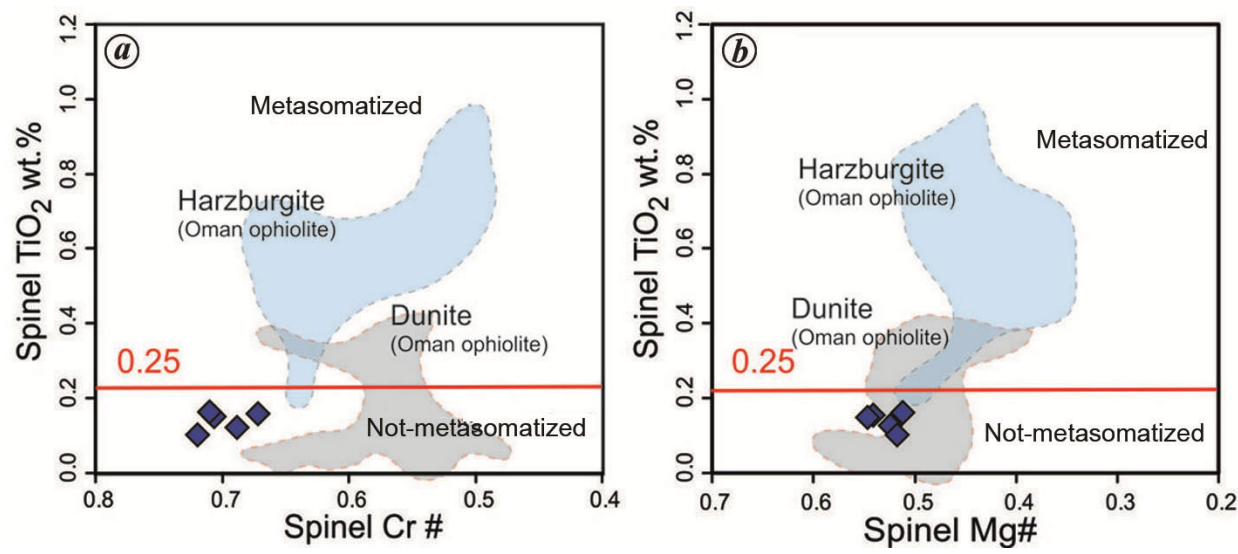

Figure 4. (a) Plots of $\mathrm{TiO}_{2} \mathrm{wt} \%$ versus $\mathrm{Cr} \#$ and (b) $\mathrm{TiO}_{2} \mathrm{wt} \%$ versus $\mathrm{Mg} \#$ for chromian spinel from the NMO dunite samples. Metasomatized and not-metasomatized chromian spinel are based on $\mathrm{TiO}_{2} \mathrm{wt} \%=0.25$ (modified after Cocomazzi et al. $^{27}$ and the references therein).

Table 2. Representative olivine chemistry of dunite from the NMO

\begin{tabular}{lrrrrr}
\hline Sample & \multicolumn{1}{c}{$\mathrm{XA} / 1$} & $\mathrm{XA} / 2$ & \multicolumn{1}{c}{$\mathrm{UT} / 1$} & \multicolumn{1}{c}{$\mathrm{UT} / 2$} & \multicolumn{1}{c}{$\mathrm{UT} / 3$} \\
\hline $\mathrm{SiO}_{2}$ & 39.15 & 40.46 & 39.11 & 40.75 & 38.78 \\
$\mathrm{TiO}_{2}$ & 0.01 & 0.01 & 0.00 & 0.01 & 0.01 \\
$\mathrm{FeO}$ & 6.13 & 7.91 & 6.72 & 7.72 & 7.18 \\
$\mathrm{MnO}$ & 0.15 & 0.19 & 0.29 & 0.17 & 0.22 \\
$\mathrm{Cr}_{2} \mathrm{O}_{3}$ & 0.02 & 0.01 & 0.01 & 0.02 & 0.01 \\
$\mathrm{MgO}$ & 53.78 & 51.31 & 52.71 & 51.57 & 53.27 \\
$\mathrm{CaO}$ & 0.03 & 0.01 & 0.03 & 0.02 & 0.01 \\
$\mathrm{Na}{ }_{2} \mathrm{O}$ & 0.01 & 0.01 & 0.01 & 0.01 & 0.01 \\
$\mathrm{~K}_{2} \mathrm{O}$ & 0.01 & 0.02 & 0 & 0.01 & 0 \\
$\mathrm{P}_{2} \mathrm{O}_{5}$ & 0.04 & 0.03 & 0.01 & 0.04 & 0.02 \\
$\mathrm{ZnO}$ & 0.25 & 0.18 & 0.26 & 0.29 & 0.21 \\
$\mathrm{Total}$ & 99.58 & 100.14 & 99.15 & 100.61 & 99.72 \\
$\mathrm{Oxygn} 4$ & & & & & \\
$\mathrm{Si}$ & 0.951 & 0.984 & 0.960 & 0.986 & 0.949 \\
$\mathrm{Ti}$ & 0.000 & 0.000 & 0.000 & 0.000 & 0.000 \\
$\mathrm{Fe}$ & 0.139 & 0.161 & 0.138 & 0.156 & 0.147 \\
$\mathrm{Mn}$ & 0.003 & 0.004 & 0.006 & 0.003 & 0.005 \\
$\mathrm{Cr}$ & 0.000 & 0.000 & 0.000 & 0.000 & 0.000 \\
$\mathrm{Mg}$ & 1.947 & 1.861 & 1.929 & 1.860 & 1.944 \\
$\mathrm{Ca}$ & 0.001 & 0.000 & 0.001 & 0.001 & 0.000 \\
$\mathrm{Na}$ & 0.000 & 0.000 & 0.000 & 0.000 & 0.000 \\
$\mathrm{~K}$ & 0.000 & 0.000 & 0.000 & 0.000 & 0.000 \\
$\mathrm{P}$ & 0.001 & 0.001 & 0.000 & 0.001 & 0.000 \\
$\mathrm{Zn}$ & 0.004 & 0.003 & 0.005 & 0.005 & 0.004 \\
$\mathrm{Mg} \#$ & 0.933 & 0.920 & 0.933 & 0.932 & 0.930 \\
$\mathrm{Fo}$ & 93.348 & 92.039 & 93.324 & 93.155 & 92.969 \\
$\mathrm{Fa}$ & 6.652 & 7.961 & 6.676 & 6.845 & 7.031 \\
\hline
\end{tabular}

samples contain 94-98 modal \% olivine, 1-3 modal \% chrome spinels and $1-2 \%$ bastite. The unaltered olivine crystals range from 0.02 to $0.3 \mathrm{~mm}$ in size and are free from any signatures of plastic deformation and recrystallization (Figure $2 c$ ). Chromian spinels are unevenly distributed in the study dunites, but rarely exceed 4 modal $\%$ of the rock (Figure $2 d$ ) and have a reddish-brown colour.

Whole-rock chemical data (major, trace and rare earth elements) were generated using X-ray fluorescence (XRF) spectrometer and inductively coupled mass plasma spectrometer (ICP-MS) at the Wadia Institute of Hima- layan Geology (WIHG), Dehradun, India. Analytical precision for major elements was within $\pm 2-3 \%$ and precision for trace elements ranged between $\pm 5 \%$ and $6 \%$. Accuracy for rare earth element (REE) analysis ranged between $2 \%$ and $12 \%$ and precision varied between $1 \%$ and $8 \%$.

Mineral chemistry for the selected dunite samples was determined using an electron microprobe analyzer (CAMECA SX100) with four spectrometers at the WIHG. Spectrometer crystal configurations used during the analyses were SP1-PET, SP2-LiF, SP3-TAP and SP4PET. The microprobe analyser was operated at an acceleration voltage of $\sim 15 \mathrm{kV}$ and probe current of $\sim 20 \mathrm{nA}$, with a beam diameter of $\sim 2 \mu \mathrm{m}$. Natural materials were used as standards and replicate analytical data of individual points showed an analytical error of $<2 \%$. We estimated $\mathrm{Fe}^{2+}$ and $\mathrm{Fe}^{3+}$ contents according to the charge balance equation proposed by Droop ${ }^{23}$. Table 1 gives the whole-rock geochemistry data of the representative dunite samples. Tables 2 and 3 show the mineral chemistry of selected olivine and chromian spinel in dunites respectively.

Olivines in the dunite samples were $\mathrm{Mg}$-rich $(\mathrm{Fo}=$ 92.03-93.34), significantly higher than the olivine composition of abyssal peridotites $(\mathrm{Fo}=90.1-90.7)$ reported from the same study area ${ }^{11}$ (Table 2). These chromian spinels had high $\mathrm{Cr} \#[\mathrm{Cr} /(\mathrm{Cr}+\mathrm{Al})]$ ranging from 0.67 to 0.71 and slightly lower $\mathrm{Mg} \#\left[\mathrm{Mg} /\left(\mathrm{Mg}+\mathrm{Fe}^{+2}\right)\right]$ values of $0.51-0.54$ (Table 3 ). FeO content ranged from 16.73 to $17.74 \mathrm{wt} \%$ and $\mathrm{TiO}_{2}$ was low $(0.10-0.16 \mathrm{wt} \%)$. Bulk rock $\mathrm{SiO}_{2}$ concentration in the dunites ranged between 39.53 and $40.89 \mathrm{wt} \%$ and they were rich in $\mathrm{MgO}$ (44.46$45.89 \mathrm{wt} \%)$. The rocks were also depleted in $\mathrm{Al}_{2} \mathrm{O}_{3}$ $(0.12-0.19 \mathrm{wt} \%), \mathrm{CaO}(0.03-0.04 \mathrm{wt} \%)$ and $\mathrm{TiO}_{2}(0.01-$ $0.02 \mathrm{wt} \%)$. They had a slightly U-shaped REEs pattern, depleted in middle REEs (MREEs), which is a different pattern from the published data of abyssal peridotites from the $\mathrm{NMO}^{11}$ (Figure 3). We used REE data from 
Table 3. Representative chromian spinel chemistry of dunite from the NMO

\begin{tabular}{|c|c|c|c|c|c|}
\hline Sample & $\mathrm{XA} / 1$ & $\mathrm{XA} / 2$ & $\mathrm{UT} / 1$ & $\mathrm{UT} / 2$ & $\mathrm{UT} / 3$ \\
\hline $\mathrm{SiO}_{2}$ & 0.04 & 0.02 & 0.01 & 0.02 & 0.03 \\
\hline $\mathrm{TiO}_{2}$ & 0.10 & 0.16 & 0.15 & 0.15 & 0.12 \\
\hline $\mathrm{Al}_{2} \mathrm{O}_{3}$ & 14.32 & 14.85 & 16.42 & 14.87 & 15.71 \\
\hline $\mathrm{Fe}_{2} \mathrm{O}_{3}$ & 1.60 & 1.37 & 3.81 & 2.77 & 3.10 \\
\hline $\mathrm{FeO}$ & 17.61 & 17.74 & 16.88 & 16.73 & 17.60 \\
\hline $\mathrm{MnO}$ & 0.22 & 0.31 & 0.27 & 0.23 & 0.32 \\
\hline $\mathrm{Cr}_{2} \mathrm{O}_{3}$ & 54.72 & 53.99 & 50.41 & 53.27 & 51.64 \\
\hline $\mathrm{MgO}$ & 10.59 & 10.42 & 11.18 & 11.25 & 10.72 \\
\hline $\mathrm{ZnO}$ & 0.27 & 0.35 & 0.37 & 0.24 & 0.15 \\
\hline Total & 99.47 & 99.21 & 99.50 & 99.53 & 99.39 \\
\hline \multicolumn{6}{|l|}{ Oxygen 32} \\
\hline $\mathrm{Si}$ & 0.010 & 0.005 & 0.003 & 0.005 & 0.008 \\
\hline $\mathrm{Ti}$ & 0.020 & 0.031 & 0.029 & 0.029 & 0.023 \\
\hline $\mathrm{Al}$ & 4.386 & 4.554 & 4.968 & 4.523 & 4.785 \\
\hline $\mathrm{Fe}^{+3}$ & 0.312 & 0.268 & 0.736 & 0.538 & 0.603 \\
\hline $\mathrm{Fe}^{+2}$ & 3.828 & 3.860 & 3.624 & 3.610 & 3.803 \\
\hline $\mathrm{Mn}$ & 0.048 & 0.068 & 0.059 & 0.050 & 0.070 \\
\hline $\mathrm{Cr}$ & 11.242 & 11.106 & 10.232 & 10.870 & 10.550 \\
\hline $\mathrm{Mg}$ & 4.102 & 4.041 & 4.278 & 4.328 & 4.129 \\
\hline $\mathrm{Zn}$ & 0.052 & 0.067 & 0.070 & 0.046 & 0.029 \\
\hline $\mathrm{Cr} \#$ & 0.719 & 0.709 & 0.673 & 0.706 & 0.688 \\
\hline $\mathrm{Mg} \#$ & 0.517 & 0.511 & 0.541 & 0.545 & 0.521 \\
\hline $\mathrm{TiO}_{2}$ melt & 0.179 & 0.259 & 0.247 & 0.247 & 0.207 \\
\hline $\mathrm{Al}_{2} \mathrm{O}_{3}$ in melt & 12.003 & 12.185 & 12.701 & 12.191 & 12.471 \\
\hline F melt & 20.706 & 20.564 & 20.042 & 20.521 & 20.260 \\
\hline$(\mathrm{FeO} / \mathrm{MgO})$ melt & 1.378 & 1.429 & 1.279 & 1.232 & 1.381 \\
\hline
\end{tabular}
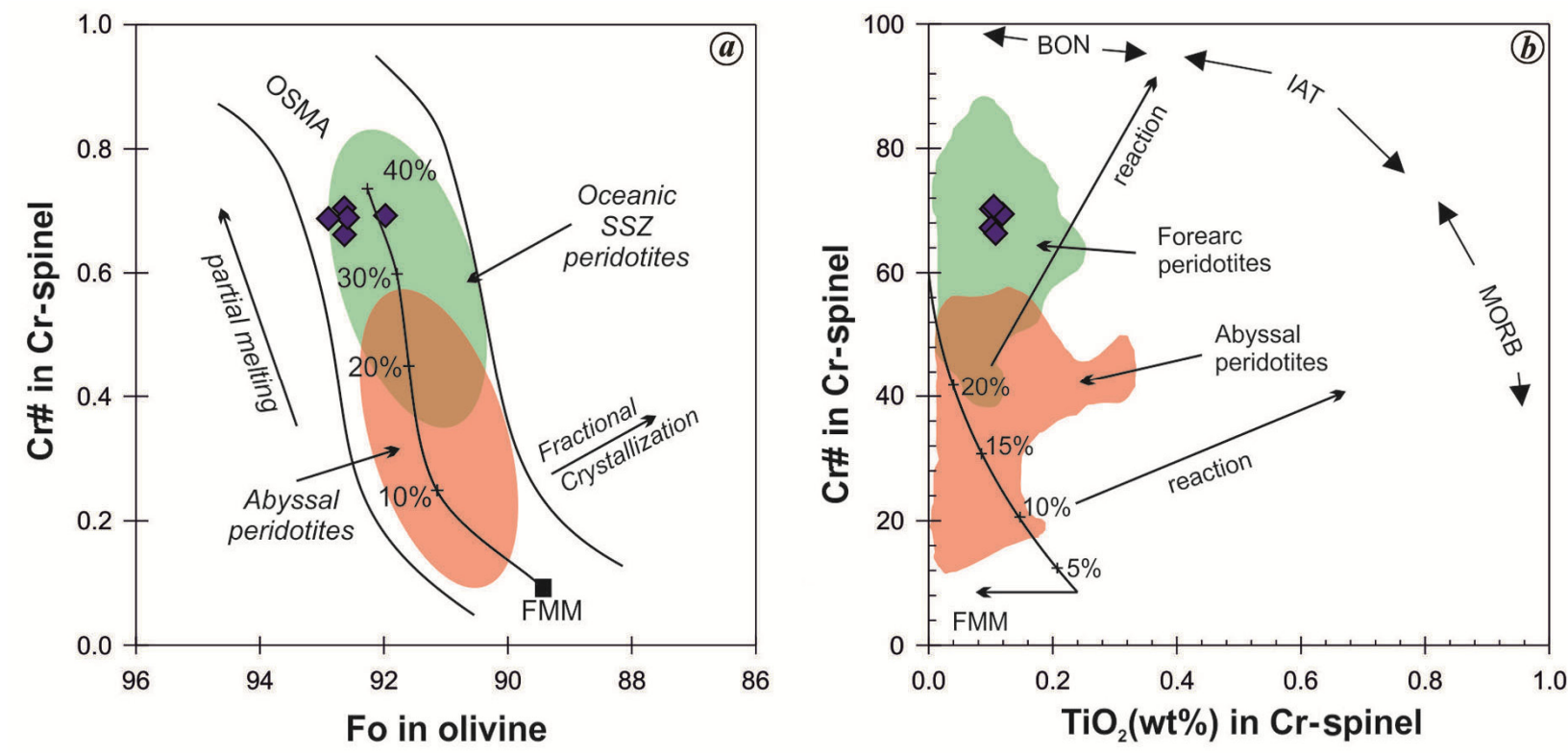

Figure 5. (a) Relationship of Cr\# in chromian spinel versus Fo content of olivine in the NMO dunites. Abyssal peridotite and oceanic supra-

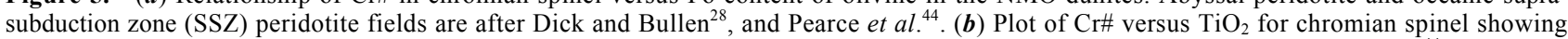
degree of melting of mantle rocks and reaction trends with boninite melts, island arc and MORB melts (fields are after Pearce et al. ${ }^{44}$ ).

Voykar ophiolite and Mirdita ophiolite for comparison $^{24,25}$. It shows that the U-shaped REE pattern of NMO dunite is equivalent to the residual dunite of Mirdita ophiolite of subduction origin, but did not match with metasomatized dunite of Voykar ophiolite (Figure 3).
Chromian spinel is one of the most significant mineral phases in mantel rocks, which usually preserves primary features even in completely serpentinized rocks or highgrade metamorphism. $\mathrm{TiO}_{2}$ content in chromian spinel is considered a valuable marker to understand rock-melt 
reaction processes. Low $\mathrm{TiO}_{2}(<0.25 \mathrm{wt} \%)$ is indicative of non-metasomatism, whereas high $\mathrm{TiO}_{2}(<0.25 \mathrm{wt} \%)$ reveals high metasomatism by rock-melt reaction ${ }^{26}$. Figure 4 show the relationship of $\mathrm{TiO}_{2}$ with $\mathrm{Cr} \#$ and $\mathrm{Mg} \#$ for chromian spinel of dunite samples of the NMO, and they plot in the field of non-metasomatism. Shaded fields of dunite and harzburgite from Oman ophiolite ${ }^{27}$ were used for comparison. The $\mathrm{Cr} \#$ of chromian spinel can also be used to calculate the degree of partial melting experienced by chromian spinel-bearing peridotites ${ }^{28-31}$. Some studies considered that the Fo content of olivine and $\mathrm{Cr} \#$ of chromian spinel do not alter during subsolidus recrystallization $^{30-32}$. In the Fo versus $\mathrm{Cr} \#$ plot (Figure $5 a$ ), the primary chromian spinels from the NMO dunite plot in the forearc peridotite field, signifying that the studied dunites originated in an arc tectonic setting. This interpretation is further supported by the $\mathrm{Cr} \#$ and $\mathrm{TiO}_{2}$ (wt\%) relationship (Figure $5 \mathrm{~b}$ ). Since $\mathrm{TiO}_{2}$ is extremely low in arc/back-arc magma, intermediate immature mid-oceanic ridge magma and high in intraplate magma, the low $\mathrm{TiO}_{2}$ concentration - less than $0.2 \mathrm{wt} \%$ in chromian spinels indicates that these studied dunites are the residual product of a subduction zone partial melting ${ }^{33}$. The high Fo (92.96-93.34) and low $\mathrm{CaO}(<0.03 \mathrm{wt} \%)$ concentration in olivine are also suggestive of residual dunite.

Al content of melt from which chromian spinels were estimated using the equation proposed by Maurel and Maurel $^{34}$. This equation is formulated based on the observation that $\mathrm{Al}_{2} \mathrm{O}_{3}\left(\mathrm{wt} \%\right.$ ) in spinel is a function of $\mathrm{Al}_{2} \mathrm{O}_{3}$ $(\mathrm{wt} \%)$ in the melt. The calculated melt composition has

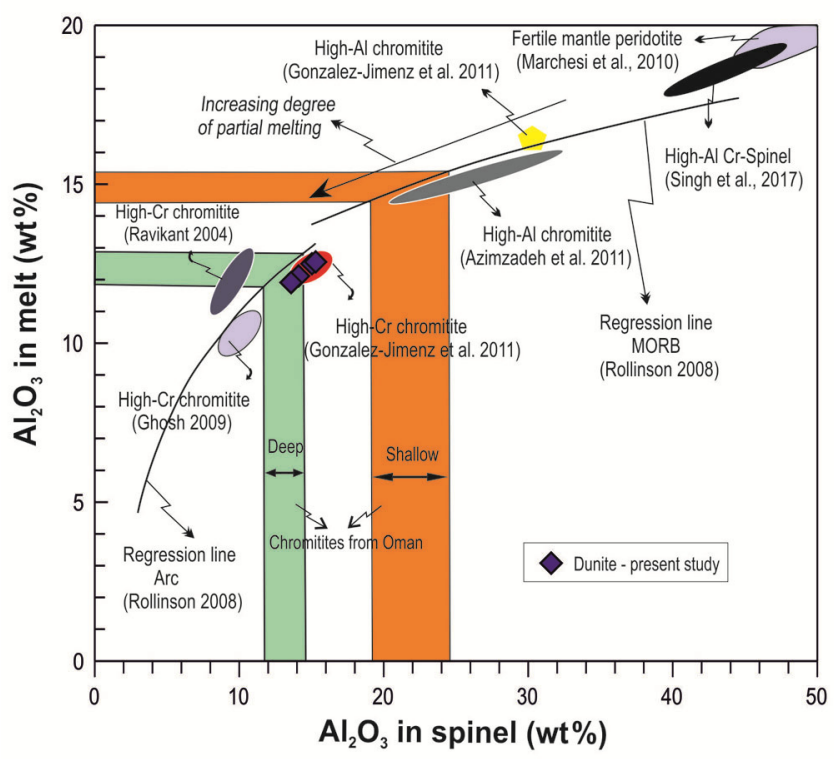

Figure 6. Compositional relationship of $\mathrm{Al}_{2} \mathrm{O}_{3}$ spinel versus $\mathrm{Al}_{2} \mathrm{O}_{3}$ melt of the NMO dunites (after Rollinson ${ }^{35}$ ). Calculated melt compositions from the high-Al and high-Cr chromitites from the Nidar ophiolites, Western Himalaya ${ }^{37}$; Rutland ophiolites, Andaman ${ }^{38}$; $\mathrm{NMO}^{39}$; Oman ophiolites ${ }^{35}$; Khoy ophiolites ${ }^{40}$ and Mayari-Cristal Ophiolite, Eastern $\mathrm{Cuba}^{41}$ are shown for comparison.
$\mathrm{Al}_{2} \mathrm{O}_{3}$ content of $12.003-12.701$. The $\mathrm{FeO} / \mathrm{MgO}$ ratio of the melt from which chromite is crystallized can be calculated using the following equation of Maurel and Maurel $^{34}$. $\quad\left\{\ln (\mathrm{FeO} / \mathrm{MgO})_{\text {Spinel }}\right\}=\left\{0.47-1.07 \mathrm{Al} \#_{\text {Spinel }}+\right.$ $\left.0.64 \mathrm{Fe}^{3+} \#_{\text {Spinel }}+\mathrm{Ln}(\mathrm{FeO} / \mathrm{MgO})_{\text {melt }}\right\}$, where $\mathrm{Al} \#_{\text {Spinel }}=$ $\mathrm{Al} /\left(\mathrm{Al}+\mathrm{Cr}+\mathrm{Fe}^{3+}\right)$ and $\mathrm{Fe}^{3+} \#_{\text {Spinel }}=\mathrm{Fe}^{3+} /\left(\mathrm{Al}+\mathrm{Cr}+\mathrm{Fe}^{3+}\right)$. It is observed that the composition of the melts parental to the chromian spinels resembles boninitic compositions $\left(\mathrm{Al}_{2} \mathrm{O}_{3 \text { melt }}=10.6-14.4 \mathrm{wt} \% ; \quad \mathrm{FeO} / \mathrm{MgO}_{\text {melt }}=0.7-1.4\right)^{35}$ and is different from the MORB parental melt $\left(\mathrm{Al}_{2} \mathrm{O}_{3 \text { melt }}=14-16 \mathrm{wt} \%\right)^{35}$. The estimated values of $\mathrm{Al}_{2} \mathrm{O}_{3}$ (12.00-12.70 wt\%) and $\mathrm{FeO} / \mathrm{MgO}$ ratio (1.23-1.42), suggest their genetic linkage with a depleted mantle source (Table 3). Figure 6 shows $\mathrm{Al}_{2} \mathrm{O}_{3}$ concentration of the melt in equilibrium with chromian spinels in dunites studied with regression lines obtained using the reported data on chromite-melt inclusions in MORB and arc lavas ${ }^{36,37}$. The range of chromian spinels and the estimated melt compositions from the high-Al chromitite and high-Cr chromitite from the Nidar ophiolites, Western Himalaya ${ }^{38}$; Rutland ophiolites, Andaman ${ }^{29}$; the $\mathrm{NMO}^{40}$; Oman ophiolites $^{36}$; Khoy ophiolites ${ }^{41}$ and Mayari-Cristal Ophiolite, Eastern $\mathrm{Cuba}^{42}$ are shown for comparison. The compositional gap between the high-Al chrome-spinels reported from peridotites of the $\mathrm{NMO}^{11,40}$ and high-Cr chromian spinels from the dunites of the NMO, together with the calculated compositions of the parental magmas, suggest that this studied chromian spinels did not originate from the same magma source.

The degree of mantle melting for the dunites studied was also calculated using the equation of Hellebrand et $\left.a l .{ }^{31}:[\mathrm{F}=10 \times \ln (\mathrm{Cr} \#)+24]\right)$, and the $\mathrm{Cr} \#$ in the chrome spinels of the dunites corresponded to a melting degree of $20.04-20.70 \%$ (Table 3 ). Using the partial melting equation proposed by Hellebrand et al. ${ }^{31}$, we estimated highdegree melting ( $20 \%$; Table 3$)$ of these dunites. These data show that the NMO dunites are the residue of peridotites that underwent extensive melting in the presence of water.

Therefore, based on our results of mineral and bulk rock geochemistry, we propose that dunites in the NMO are residual mantle section of extensive partial melting in the mantle wedge of a subduction zone. Low $\mathrm{TiO}_{2}$ and high $\mathrm{Mg \#}$ in chrome spinels suggest the absence of metasomatism, which indicates no melt-rock interaction had occurred during the partial melting process and emplacement. The absence of metasomatism is also supported by a depleted MREE pattern similar to non-metasomatic dunites of other ophiolites. In conclusion, although the NMO shows ample evidence for MORB-plume interaction, the presence of dunites is key evidence for subduction zone extensive partial melting.

1. Miyashiro, A., The Troodos ophiolitic complex was probably formed in island arc. Earth Planet. Sci. Lett., 1973, 19, 218-224. 


\section{RESEARCH COMMUNICATIONS}

2. Pearce, J. A., Alabaster, T., Shelton, A. W. and Searle, M. P., The Oman ophiolite as a Cretaceous arc-basin complex: evidence and implications. In Extensional Tectonics Associated with Convergent Plate Boundaries: A Royal Society Discussion (eds Vine, F. J. and Smith, A. G.), Royal Society of London, UK, 1981, pp. 299-317.

3. Portnyagin, M. V., Danyushevsky, L. V. and Kemenetsky, V. S., Coexistence of two distinct mantle sources during formation of ophiolites: a case study of primitive pillow-lavas from the lowest part of the volcanic section of the Troodos ophiolite, Cyprus. Contrib. Mineral. Petrol., 1997, 128, 287-301.

4. Saccani, E., Beccaluva, L., Coltorti, M. and Siena, F., Petrogenesis and tectono-magmatic significance of the Albanide-Hellenide ophiolites. Ofioliti, 2004, 29, 77-95.

5. Aldanmaz, E., Schmidt, M. W., Gourgaud, A. and Meisel, T., Mid-ocean ridge and suprasubduction geochemical signatures in spinel-peridotites from the Neotethyan ophiolites in SW Turkey: implications for upper mantle melting processes. Lithos, 2007, 113, 691-708.

6. Bedard, E., Hebert, R., Guilmette, C., Lesage, G., Wang, C. S. and Dostal, J., Petrology and geochemistry of the Saga and Sangsang ophiolitic massifs, Yarlung Zangbo Suture Zone, Southern Tibet: evidence for an arc-back-arc origin. Lithos, 2009, 113, 48-67.

7. Dilek, Y. and Furnes, H., Ophiolite genesis and global tectonics: geochemical and tectonic finger printing of ancient oceanic lithosphere. Geol. Soc. Am. Bull., 2011, 123, 387-411.

8. Sengupta, S., Acharyya, S. K., Vandenhul, H. J. and Chattopadhyay, B., Geochemistry of volcanic rocks from the Naga Hills Ophiolites, northeast India and their inferred tectonic setting. J. Geol. Soc. London, 1998, 146, 491-498.

9. Acharyya, S. K., Collisional emplacement history of the NagaAndaman ophiolites and the position of the eastern Indian suture. J. Asian Earth Sci., 2007, 29, 229-242.

10. Singh, A. K., High-Al chromian spinel in peridotites of Manipur Ophiolite Complex, Indo-Myanmar Orogenic Belt: implication for petrogenesis and geotectonic setting. Curr. Sci., 2009, 96, 973978.

11. Singh, A. K., Petrology and geochemistry of abyssal peridotites from the Manipur ophiolite complex, Indo-Myanmar orogenic belt, Northeast India: implication for melt generation in midoceanic ridge environment. J. Asian Earth Sci., 2013, 66, 258276.

12. Singh, A. K., Devi, L. D., Singh, N. I., Subramanyam, K. S. V., Bikramaditya, R. K. and Satyanarayanan, M., Platinum-group elements and gold distributions in peridotites and associated podiform chromitites of the Manipur Ophiolitic Complex, IndoMyanmar Orogenic Belt, Northeast India. Chem. Erde-Geochem., 2013, 73, 147-161.

13. Ao, A. and Bhowmik, S. K., Cold subduction of the Neotethys: the metamorphic record from finely banded lawsonite and epidote blueschists and associated metabasalts of the Nagaland Ophiolite Complex, India. J. Metamorph. Geol., 2014, 32, 829-860.

14. Singh, A. K., Khogenkumar, S., Singh, L. R., Bikramaditya, R. K., Khuman Ch. M. and Thakur, S. S., Evidence of mid-ocean ridge and shallow subduction forearc magmatism in the NagalandManipur ophiolites, northeast India: constraints from mineralogy and geochemistry of gabbros and associated mafic dykes. Chem. Erde-Geochem., 2016, 76, 605-620.

15. Khogenkumar, S., Singh, A. K., Bikramaditya Singh, R. K., Khanna, P. P., Singh, N. I. and Singh, W. I., Coexistence of MORB and OIB-type mafic volcanics in the Manipur Ophiolite Complex, Indo-Myanmar Orogenic Belt, northeast India: implication for heterogeneous mantle source at the spreading zone. J. Asian Earth Sci., 2016, 116, 42-58.

16. Zaccarini, F., Singh, A. K. and Garuti, G., Platinum Group Minerals and silicate inclusions in chromitite from the Naga-Manipur Ophiolite Complex, Indo-Myanmar Orogenic Belt, Northeast India. Can. Mineral., 2016, 54(2), 409-427.
17. Rajkakati, M., Bhowmik, S. K., Ao, A., Ireland, T. R., Avila, J., Clarke, G. L., Bhandari, A. and Aitchison, J. C., Thermal history of Early Jurassic eclogite facies metamorphism in the Nagaland Ophiolite Complex, NE India: new insights into pre-Cretaceous subduction channel tectonics within the Neo-Tethys. Lithos, 2019, 346-347, 105166.

18. Mitchell, A. H. G., Phanerozoic plate boundaries in mainland SE Asia, the Himalayas and Tibet. J. Geol. Soc. London, 1981, 138, 109-122.

19. Bhattacharjee, C. C., The ophiolites of northeast India - a subduction zone ophiolite complex of the Indo-Myanmar Orogenic belt. Tectonophysics, 1991, 191, 213-222.

20. Ghose, N. C., Agrawal, O. P. and Chatterjee, N., Geological and mineralogical study of eclogite and glaucophane schists in the Naga Hills Ophiolite, Northeast India. Island Arc, 2010, 19, 336356.

21. Singh, A. K., Singh, N. I., Devi, L. D. and Singh, R. K. B., Geochemistry of Mid-Ocean Ridge mafic intrusives from the Manipur Ophiolitic Complex, Indo-Myanmar Orogenic Belt, NE India. J. Geol. Soc. India, 2012, 80, 231-240.

22. Singh, A. K., Singh, N. I., Devi, L. D. and Singh, R. K. B., Pillow basalts from the Manipur Ophiolitic Complex (MOC), Indo-Myanmar Range, Northeast India. J. Geol. Soc., 2008, 72 , 168-174.

23. Droop, G. T. R., A general equation for estimating $\mathrm{Fe}^{3+}$ concentrations in ferromagnesian silicates and oxides from microprobe analyses, using stoichiometric criteria. Mineral. Mag., 1987, 51, $431-435$.

24. Batanova, V. G., Belousov, I. A., Savelieva, G. N. and Sobolev, A. V., Consequences of channelized and diffuse melt transport in supra-subduction zone mantle: evidence from the Voykar Ophiolite (Polar Urals). J. Petrol., 2011, 52(12), 2483-2521.

25. Wu, W., Yang, J., Dilek, Y., Milushi, I. and Lian, D., Multiple episodes of melting, depletion, and enrichment of the Tethyan mantle: petrogenesis of the peridotites and chromitites in the Jurassic Skenderbeu massif, Mirdita ophiolite, Albania. Lithosphere, 2017, 10(1), 54-78.

26. Tartarothi, P., Supini, S., Nimis, P. and Ottolini, L., Melt migration in the upper mantle along the Romanche fracture zone (Equatorial Atlantic). Lithos, 2002, 63, 125-149.

27. Cocomazzi, G., Grieco, G., Tartarotti, P., Bussolesi, M., Zaccarini, F., Crispini, L. and Oman Drilling Project Science Team, The formation of dunite channels within Harzburgite in the Wadi Tayin Massif, Oman Ophiolite: insights from compositional variability of Cr-spinel and olivine in holes BA1B and BA3A, Oman Drilling Project. Minerals, 2020, 10(2), 167; https://doi.org/ 10.3390/min 10020167.

28. Dick, H. J. B. and Bullen, T., Chromian spinel as a petrogenetic indicator in abyssal and alpine type peridotites and spatially associated lavas. Contrib. Mineral. Petrol., 1984, 86, 54-76.

29. Michael, P. J. and Bonatti, E., Peridotite composition from the North Atlantic: regional and tectonic variations and implications for partial melting, Earth Planet. Sci. Lett., 1985, 73, 91-104.

30. Arai, S., Characterization of spinel peridotites by olivine-spinel compositional relationships: review and interpretation. Chem. Geol., 1994, 113, 191-204.

31. Hellebrand, E., Show, J. E., Dick, H. J. B. and Hofmann, A. W., Coupled major and trace elements as indicators of the extent of melting in the midocean-ridge peridotites. Nature, 2001, 410, 677-681.

32. Ozawa, K., Ultramafic tectonite of the Miyamori ophiolitic complex in the Kitakami Mountains, northeast Japan: hydrous upper mantle in an island arc. Contrib. Mineral. Petrol., 1988, 99, 159175.

33. Arai, S., Chemistry of chromian spinel in volcanic rocks as a potential guide to magma chemistry. Mineral. Mag., 1992, 56, 173-184. 
34. Maurel, C. and Maurel, P., E'tude expe'rimental de la distribution de l'aluminium entre bain silicate basique et spinelle chromife're. Implications pe'trogenetiques: teneur en chrome des spinelles. Bull. Mineral., 1982, 105, 197-202.

35. Wilson, M., Igneous Petrogenesis: A Global Tectonic Approach, Unwin Hyman, London, UK, 1989, p. 446.

36. Rollinson, H., The geochemistry of mantle chromitites from the northern part of the Oman ophiolite: inferred parental melt compositions. Contrib. Mineral. Petrol., 2008, 156, 273-288.

37. Kamenetsky, V. S., Crawford, A. J. and Meffre, S., Factors controlling chemistry of magmatic spinel: an empirical study of associated olivine, $\mathrm{Cr}$-spinel and melt inclusions from primitive rocks. J. Petrol., 2001, 42, 655-671.

38. Ravikant, V., Pal, T. and Das, D., Chromites from the Nidar ophiolite and Karzok complex, Trans Himalaya, eastern Ladakh: their magmatic evolution. J. Asian Earth Sci., 2004, 24, 177-184.

39. Ghosh, B., Pal, T., Bhattacharya, A. and Das, D., Petrogenetic implications of ophiolitic chromite from Rutland Island, Andaman a boninitic parentage in supra-subduction setting. Mineral. Petrol., 2009, 96, 59-70.

40. Singh, A. K., Chung, S. L., Bikramaditya, R. K. and Lee, H. Y., New $\mathrm{U}-\mathrm{Pb}$ zircon ages of plagiogranites from the NagalandManipur Ophiolites, Indo-Myanmar Orogenic Belt, NE India. $J$. Geol. Soc., London, 2017, 174, 170-179.

41. Azimzadeh, A. M., Zaccarini, F., Moayyed, M., Garuti, G., Thalhammer, O. A. R., Uysal, I. and Mirmohammadi, M., Magmatic and post-magmatic significance of chromitite and associated platinum-group minerals (PGM) in the Eastern Khoy ophiolitic complex (NW Iran). Ofioliti, 2011, 36, 157-173.

42. González-Jiménez, J. M., Proenza, J. A., Gervilla, F., Melgarejo, J. C., Blanco-Moreno, J. A., Ruiz-Sánchez, R. and Griffin, W. L., High-Cr and high-Al chromitites from the Sagua de Tánamo district, Mayarí-Cristal Ophiolitic Massif (eastern Cuba): constraints on their origin from mineralogy and geochemistry of chromian spinel and platinum-group elements. Lithos, 2011, 125, 101-121.

43. Vidyadharan, K. T., Joshi, A., Ghose, S., Gaur, M. P. and Sukla, R., Manipur Ophiolites. Its geology, tectonic setting and metallogeny. In Phanerozoic Ophiolites of India (ed. Ghose, N. C.), Sumna Publication, Patna, 1989, pp. 197-212.

44. Pearce, J. A., Barker, P. F., Edwards, S. J., Parkinson, I. J. and Leat, P. T., Geochemistry and tectonic significance of peridotites from the South Sandwich arc-basin system, South Atlantic. Contrib. Mineral. Petrol., 2000, 139, 36-53.

ACKNOWLEDGEMENTS. We thank the Director, Wadia Institute of Himalayan Geology, Dehradun for encouragement and providing the necessary laboratory facilities. This study was supported by the Ministry of Earth Sciences (MoES), Government of India through a research grant (No. MoES/P.O.(Geo)/80/2015) to A.K.S. We thank the two anonymous reviewers for useful suggestions and Prof. N. V. Chalapathi Rao for his editorial handling of this manuscript.

Received 30 June 2020; revised accepted 31 December 2020

doi: $10.18520 / \mathrm{cs} / \mathrm{v} 120 / \mathrm{i} 8 / 1381-1388$

\section{Food plasticity for mating and reproductive success in Propylea dissecta (Mulsant) (Coleoptera: Coccinellidae)}

\author{
Priya Singh, Geetanjali Mishra and Omkar* \\ Ladybird Research Laboratory, Department of Zoology, \\ University of Lucknow, Lucknow 226 007, India
}

Food supply at each life stage is of prime importance that determines the organism's fitness and also influences individual's reproductive performance and development. In this contest, we assessed the interactive effect of both larval and adult food regimes in Propylea dissecta (Mulsant) individuals. For this, egg batches were randomly selected and hatched larvae (larval diet) were reared into two food regimes, abundant (A) and scarce (S) till pupation. Post-emergence (adult stage) the ladybird beetles of each food regime were divided into two groups, abundant and scarce and at the age of 10 days adults were paired in all possible combinations. The results showed that individuals that were reared on abundant food mated for longer and showed higher reproductive output than other individuals. The adults provided with scarce and abundant food regime both irrespective of life stages showed similar mating durations and reproductive output. Food supply at larval and adult stages in both sexes plays important role in determining the reproductive success.

Keywords: Fecundity, food supply, ladybird, reproduction, viability.

THE distribution and allocation of resources has critical consequences on individual's development and growth ${ }^{1-3}$. In particular, the accessibility of adequate food supply is one of the prime factors modifying growth of organism, development and reproduction in animals ${ }^{4-6}$.

Food quality and quantity can fluctuate extensively in different landscapes ${ }^{7}$ and food shortage during larval development increases the duration of development. Food scarcity also decreases organisms growth rate and body mass as well as modifies the individuals reproductive output in later lives ${ }^{5,8,9}$.

Earlier studies have reported that both larval and adult stages of ladybird beetles have potential to survive in prolonged food stress conditions ${ }^{10,11}$, but their reproductive performance might be a constraint in comparison to adults given opportunity to feed on ad libitum aphid supply $^{12-14}$. Few more studies have found that the food available to coccinellid larvae has a direct influence on the reproductive fitness of the resulting adults ${ }^{14-16}$. Dixon and Guo ${ }^{17}$ suggested that this may be the result of food

*For correspondence. (e-mail: omkar.lkouniv@gmail.com) 